\title{
Raziskave digitalizacije branja in pisanja ter medijske večopravilnosti - kakšne so spremembe na kognitivnem, čustveno-socialnem in nevrološkem področju ter v učnih dosežkih?
}

\section{Simona Tancig}

\section{Uvod}

Spretnosti branja in pisanja so bistvene za uspešnost v današnji družbi. Zato se še posebna velika pozornost posveča opismenjevanju. Današnji digitalni čas zaznamuje izjemno pomembna prelomnica $\mathrm{v}$ zgodovini pisave, pisanja in branja. Prvič v zgodovini človeštva se pojavljajo težnje, da bi se opustilo učenje pisanja $z$ roko in ga nadomestilo s tipkovnico - $z$ dolgoročno posledico, da sčasoma nihče ne bo več znal brati ročno napisane pisave, enega najpomembnejših civilizacijskih dosežkov. Podobno se pri branju kažejo težnje, da se na papirju tiskana besedila nadomestijo z besedili na digitalnih nosilcih.

Da bi odgovorili na vprašanje, kaj izgubimo in kaj pridobimo s temi spremembami, se je v zadnjem desetletju zvrstilo veliko število interdisciplinarnih raziskav in projektov, katerih cilj je izboljšati znanstveno razumevanje vpliva digitalizacije na bralno pismenost. Njihov namen je tudi nuditi pomoč različnim disciplinam in družbenim dejavnikom (edukacijski politiki, praktikom v izobraževanju, založnikom ipd.).

Pomembno mesto $\mathrm{v}$ teh prizadevanjih ima program COST Evropske zveze, ki povezuje znanost in tehnologijo s projektom E-READ (COST-IS1404, 2014), ki je združeval 70 evropskih raziskovalcev s področja nevroznanosti, družboslovja, humanistike in informacijske tehnologije pod vodstvom Anne Mangen iz Univerze Stavanger na Norveškem (Mangen in Weel, 2016). Razvita je bila nova raziskovalna paradigma, ki temelji na mul- 
tidimenzionalnem integrativnem modelu branja in različnih eksperimentalnih pristopih ter na edukometriki za preverjanje in ocenjevanje vpliva digitalizacije na branje. Projekt se je po štirih letih lansko leto končal z Deklaracijo iz Stavangerja o prihodnosti branja (COST-IS1404, 2019), ki podaja glavne ugotovitve raziskav, priporočila za edukacijsko politiko in vzgojno-izobraževalno prakso ter vprašanja za nadaljnje raziskave.

\section{Utelešena kognicija}

Sodobne teorije v kognitivni znanosti poudarjajo, da je kognicija utelešena (Glenberg, 2008; Thompson, 2007; Varela et al., 1991). To pomeni, da percepcija, telesna aktivnost in čustva pomembno prispevajo k višjim kognitivnim procesom (Gallese in Lakoff, 2005). Z utelešeno kognicijo se v okviru post-kognitivistične paradigme ukvarjajo številne konstitutivne vede kognitivne znanosti, kot so filozofija, psihologija, kognitivna nevroznanost, robotika, lingvistika - poleg še nekaterih drugih.

Utelešena kognicija je tudi predmet pomembnih razprav in raziskav $\mathrm{v}$ edukacijski nevroznanosti (nevroedukaciji) ozir. znanosti o človekovem umu, možganih in edukaciji.

Najnovejše razumevanje utelešene kognicije se uveljavlja na različnih področjih, kot so: spomin, konkretni in abstraktni pojmi, številčnost, aritmetika, branje in pisanje (Kiefer in Trumpp, 2012; Kiefer in Pulvermüller, 2012). Raziskave utelešene kognicije imajo pomembne implikacije $\mathrm{v}$ edukaciji kot tudi širše $\mathrm{v}$ današnji digitalni dobi, ki pomembno spreminja vlogo senzo-motorike, percepcije in telesne aktivnosti $v$ učenju in poučevanju ter reševanju problemov, ki jih prinaša sodobna družbena realnost.

Teorija utelešene kognicije dobiva vedno večjo podporo s psihološki$\mathrm{mi}$ in nevroznanstvenimi raziskavami, ki dokazujejo tesno povezanost med senzoričnimi in motoričnimi sistemi ter kognicijo (Kiefer in Barsalou, 2013).

Tehnike slikanja možganov, elektrofiziološke meritve, vedenjski eksperimenti (priming) in nevrofiziološke študije dajejo neposredne dokaze o vključevanju specifičnih senzoričnih in motoričnih sistemov med izvrševanjem kognitivnih nalog. Novejše raziskave utelešene kognicije na različnih kognitivnih področjih imajo pomembne posledice za učenje in poučevanje ter podpirajo širše vključevanje senzomotoričnih dejavnosti $\mathrm{v}$ poučevanje na različnih predmetnih področij - učenje skozi gibanje (Tancig, 2014a, 2014b). 
Teorija utelešene kognicije predpostavlja, da na branje vpliva pisanje kot tudi same tehnike pisanja, ker se motorični programi in senzorične izkušnje, pridobljeni med pisanjem, ponovno aktivirajo med branjem. Ti programi in izkušnje pa se zelo razlikujejo pri pisanju s pisalom na papir v primerjavi s tipkanjem na tipkovnico. Podobno se senzomotorične izkušnje močno razlikujejo pri branju s papirja $\mathrm{v}$ primerjavi $\mathrm{z}$ branjem besedila na digitalnih nosilcih.

\section{Zakaj je pisanje pomembno za branje}

S slikanjem možganov s funkcionalno magnetno resonanco (fMRI) sta Nakamura in Dehaene s sodelavci (Nakamura et al., 2012) tako pri francoskih kot pri kitajskih bralcih ugotovila, da sta bila vključena tako vizualni kot tudi motorični sistem za geste (kretnje), ko so udeleženci brali rokopisno besedilo v materinem jeziku. Branje tako vključuje dve živčni omrežji - eno, ki prepoznava obliko besed (VWFA - vizualno področje oblike besed), in drugo, ki dekodira fizične motorične geste, sodelujoče pri pisanju (Exnerjevo področje). Motorično procesiranje je pri pisanju univerzalno in vključuje področje, poimenovano Exnerjevo, ki se torej aktivira tudi pri branju ne glede na jezikovno kulturo.

Obe univerzalni omrežji - sistem za prepoznavanje oblik in sistem za prepoznavanje gest - se podobno aktivirata in kažeta identični vzorec aktivacije v obeh jezikovnih skupinah (Dehaene, 2014). Vizualni sistem oblike besed (VWFA) je občutljiv za statično zaporedje niza črk in Exnerjevo področje je občutljivo za smeri kretenj naprej in nazaj, s katerimi so dinamično predstavljene črke rokopisa.

\section{Pisati ali tipkati}

\section{Razlike v nevrokognitivnih procesih}

Nevroznanstvene raziskave so potrdile, da se pri pisanju $\mathrm{z}$ roko aktivirajo druga možganska področja kot pri tipkanju. Različne raziskave dokazujejo, da pisanje bolj spodbuja delovanje možganov kot tipkanje.

Tako so Longcamp et al. (2005) v raziskavi predšolskih otrok ugotovili, da so bolj uspešni pri prepoznavanju črk, če jih vadijo s pisanjem kot $s$ tipkanjem. Omenjeni raziskovalci so predpostavili, da pisanje podpira notranji model črk zaradi integracije vida, motoričnih ukazov in kinestetične povratne informacije, česar tipkanje ne omogoča. Podobno so bili tudi odrasli, ki so se učili pisati nove, t.i. psevdočrke, boljši po 3 in 6 tednih pri nji- 
hovem zapomnjenju in prepoznavanju njihove pravilne orientacije, če so jih pisali $\mathrm{z}$ roko.

Pri njih so s snemanjem možganske aktivnosti ugotovili, da je bilo zaznati aktivnost $\mathrm{v}$ možganskem predelu, odgovornem za artikulacijo in produkcijo govora (t.i. Brockovo področje v možganski skorji), medtem ko pri tipkajočih $\mathrm{v}$ tem področju ni bilo zaznati skoraj nobene aktivnosti.

Pomembne informacije za prakso je dala tudi raziskava avtoric Kersey in James (2013), $v$ kateri so otroci imeli aktiven trening s pisanjem in pasivnega $\mathrm{z}$ opazovanjem druge osebe pri pisanju; aktivacijo možganov so pri tem ugotavljali s fMRI. Rezultati so pokazali, da aktivni trening pisanja privede do večjega vključevanja senzomotoričnega omrežja, povezanega s percepcijo črk, medtem ko tega ni zaznati pri pasivnem opazovanju. To kaže, da je perceptivno omrežje za novo naučene pisane črke bolj upravljano z motorično izvedbo kot pa s povratno perceptivno informacijo.

Zanimiva je zelo kompleksna raziskava, s katero sta James in Engelhardt (2012) preverili, kako različne senzomotorične dejavnosti ozir. izkušnje vplivajo na obravnavanje črk $\mathrm{v}$ možganih. $\mathrm{V}$ raziskavi so sodelovali 5-letni otroci, ki se še niso učili brati in pisati. Otrokom so pokazali različne črke in oblike, ki so jih nato reproducirali na tri načine: tako, da so jih prostoročno prerisali na prazen papir; s sledenjem črke ali oblike, označene s pikami na predlogi; s pritiskom na ustrezno tipko. Nato so jim pokazali slike teh črk in oblik ter pri tem s fMRI snemali njihovo možgansko dejavnost. Rezultati so pokazali, da se je predhodno dokumentirano „bralno omrežje" aktiviralo samo med percepcijo črk in oblik, ki so jih otroci narisali prostoročno, ne pa med percepcijo tistih, ki so jih izvajali s sledenjem po predlogi ali s tipkanjem, kjer je bila aktivacija možganov bistveno manjša. Te ugotovitve kažejo, da je pisanje pomembno za zgodnje aktiviranje možganskih področij pri procesiranju črk, ki je osnova uspešnega branja. Torej pisanje pri otrocih spodbuja pridobivanje bralne spretnosti. James (2012) je $\mathrm{z}$ raziskavo ugotovila, da pisanje prispeva tudi $\mathrm{k}$ bralni fluentnosti $\mathrm{z}$ aktivacijo vizualne percepcije črk s povečanjem natančnosti ter hitrosti prepoznavanja črk.

\section{Razlike v kognitivnih procesih in učenju}

Berninger et al. (2009) so izvedli raziskavo pri učencih četrtega razreda $\mathrm{z}$ učnimi težavami na področju pisanja in črkovanja ter tistimi brez učnih težav. Raziskava je bila del širšega 5-letnega longitudinalnega projekta, v katerem je sodelovalo 240 učencev drugega, četrtega in šestega razreda. 
Učence $\mathrm{z}$ in brez omenjenih učnih težav so primerjali na treh nalogah pisanja (črke, stavki, pisanje eseja) s pisalom in z uporabo tipkovnice.

Rezultati so pokazali, da so učenci s pisalom napisali daljši esej s hitrejšo produkcijo besed kot s tipkovnico. Poleg tega so učenci četrtega in šestega razreda pisali bolj popolne stavke, ko so pisali s pisalom, kot s tipkovnico. Dodatna analiza je pokazala, da je število idej, izraženih v esejih, bilo večje pri pisanju v primerjavi s tipkanjem.

Glede na to, da se pri študentih vedno bolj širi praksa zapisovanja predavanj s prenosnim računalnikom, ki nadomešča zapiske, pisane s pisalom, sta Müeller in Oppenheimer (2014) raziskala učinkovitost obeh načinov zapisovanja pri študiju.

Izvedla sta tri eksperimentalne študije $\mathrm{v}$ naravnem okolju. $\mathrm{V}$ prvem eksperimentu so študenti poslušali isto predavanje, pri tem pa so nekateri delali zapiske v beležke in drugi v prenosnik. Pri tem so dobili navodilo, da naj uporabljajo svojo običajno strategijo zapisovanja. Po predavanju so vse študente preizkusili v priklicu dejstev in konceptualnem znanju iz vsebine predavanja. Ugotovili so enako uspešnost obeh skupin pri faktografskem znanju, vendar so bili študenti s prenosniki slabši pri konceptualnem znanju.

Zanimivo je, da se je tudi pri drugi različici eksperimenta, ko so uporabnikom prenosnika dali navodilo, naj predavanja ne zapisujejo dobesedno, ta intervencija pokazala za povsem neuspešno. Študenti so z uporabo prenosnika še vedno delali verbatim zapiske, kar je poslabšalo njihovo učenje. Ponovno se je pokazala povezava med slabšim konceptualnim znanjem in verbatim zapiski. Čeprav so ti zapiski obsežnejši in bolj berljivi, očitno način s tipkanjem bolj vodi v proces zapisovanja „brez misli“. In na drugi strani je zapisovanje s pisalom tisto, ki omogoča aktivnejše procesiranje informacij z njihovim selekcioniranjem glede na pomembnost, s preoblikovanjem, s parafraziranjem, $\mathrm{z}$ označevanjem ipd.

Ker študenti v predhodnih dveh študijah niso imeli možnosti pregledati in preštudirati gradiva $\mathrm{v}$ zapiskih, so jim $\mathrm{v}$ ponovljenem eksperimentu omogočili, da se pripravijo na izpit. Rezultati so bili tudi tokrat presenetljivi. Tisti, ki so delali zapiske $s$ pisanjem $\mathrm{v}$ beležke, so bili pomembno boljši kot kdor koli iz druge skupine. Boljši so bili tudi od tistih, ki so v celoti transkribirali predavanje. Študenti, ki so beležili predavanje s pisanjem, so v splošnem zapisali manj informacij kot tudi manj dobesedno. Vendar so bili boljši v faktografskem kot tudi v višjenivojskem znanju. Avtorja domnevata, da zapisovanje s pisalom ne samo, da vodi $\mathrm{v} k v a l i t e t n e j-$ 
še učenje, temveč je tudi boljša strategija za uskladiščenje novega učenja za poznejši študij.

Če povzamemo. Nevroznanstvene in nevroedukacijske raziskave kažejo, da je branje tesno povezano s pisanjem in da pisanje veliko bolj spodbuja bralno zmožnost kot tipkanje. Nesporno je, da je pisanje z roko pomembno za učenje branja in prispeva $\mathrm{k}$ tekočemu branju. In ne samo to, raziskave tudi kažejo prednosti pisanja z roko pri zapomnjenju in razumevanju učnega gradiva, pri osvajanju pojmov, pri razvoju spominskih in izvršilnih funkcij, refleksivnega učenja in višjenivojskega znanja kot tudi pri razvoju fine motorike, koordinacije oko-roka, spacializacije ipd. Pisanje $z$ roko je torej pomembno tudi za razvoj različnih kognitivnih funkcij in ne samo za učenje branja (Tancig, 2014).

\section{Kaj loči branje knjige od branja besedila na digitalnem nosilcu}

Podobno kot pri pisanju se tudi pri branju ugotavljajo razlike glede na medij, ki ga uporabljamo pri branju - tiskano gradivo ali bralnik Kindle ozir. tablica ali kakšen drugi digitalni pripomoček. Norveška raziskovalka Anne Mangen, vodja nove evropske raziskovalne mreže, ki je raziskovala, kako digitalizacija vpliva na branje besedil, ugotavlja, da je pri branju besedil v elektronski obliki težko vzdrževati daljšo pozornost, zato je branje bolj prekinjeno in razdrobljeno, kot tudi, da negativno vpliva na nekatere kognitivne (razumevanje) in emocionalne vidike branja (Mangen in Kuiken, 2014). Podobno kot pri pisanju je potrebno tudi pri branju iskati razlage omenjenih rezultatov v bistveno drugačnih senzoričnih (vidnih in tipnih) ter motoričnih oz. haptičnih značilnostih, ki ločijo branje knjige od uporabe digitalnega nosilca.

\section{Dve dimenziji utelešene kognicije}

Govorimo o haptičnosti, ki je opredeljena kot kombinacija tipne percepcije $z$ gibalno aktivnostjo, ki sproža propriorecepcijo ${ }^{1}$. Pri namernem premikanju rok - bodisi, da gre za raziskovanje ali rokovanje s predmeti - je vključena haptična percepcija, ki je velikega pomena pri pisanju in branju.

Drug pomemben vidik, ki stopa $v$ ospredje pri pojmovanju utelešene kognicije pri branju v digitalni dobi, izhaja iz ekološke psihologije Gibsona (1979), ki poudarja možnosti za akcijo in interakcijo z okoljem ali objek- 
tom (affordance), npr. možnosti za interakcijo z digitalnim sredstvom, kot jih zaznava oseba. Tako se rokovanje ozir. interakcija s pisalom ali tipkovnico pomembno razlikujeta, podobno kot se pomembno razlikuje interakcija s knjigo v primerjavi z interakcijo s tablico, kar vse pomembno vpliva na bralno uspešnost in višje kognitivne procese.

\section{Haptičnost in interakcija $z$ objektom pisanja in tipkanja}

Pisanje in tipkanje se razlikujeta glede dimenzij haptičnosti in interakcije $z$ objektom pisanja - pisalom ozir. tipkovnico. Pisanje z roko tipično označuje npr. omejen prostor pisanja (list papirja), ki je skupen za vizualno in motorično dejavnost $-\mathrm{z}$ očmi sledimo gibanju s pisalom. Za vsako črko je značilen specifičen gib (grafomotorika). Pri tem je odnos med vizualno obliko in motoričnim programom enoznačen. Pri tipkanju sta vizualni prostor (ekran) in motorični prostor (tipkovnica) ločena. Vsak gib (pritisk na tipko), ki je enostaven in enak za vse črke, je povezan s položajem tipke, pri čemer je pomembno učenje ozir. poznavanje sheme tipkovnice.

V okviru mednarodnega podiplomskega študija kognitivne znanosti v Ljubljani je bila pod mentorstvom avtorice opravljena raziskava o razlikah $v$ doživljanju pisanja $z$ roko in tipkanjem (Demšar, 2015). Uporabljena je bila metoda fenomenološkega intervjuja ter opazovanja in analize posnetkov dejavnosti. Večina udeležencev je poročala o podobnih ozir. enakih razlikah v subjektivnih izkušnjah tako pri pisanju na roko (bolj osredotočena pozornost, večja zavzetost, več razmišljanja in načrtovanja, tekoča aktivnost, večja povezava s tekstom, večja vključenost telesa) kot pri tipkanju (večja razdrobljenost izkušnje, pričakovanje napak, pomanjkanje stika $\mathrm{z}$ besedilom, tekst manj resničen in pomemben, okolica vplivala bolj moteče).

\section{Haptičnost in interakcija $z$ objektom branja glede na nosilec besedila}

Razlike so tudi $\mathrm{v}$ haptičnosti in interakciji z objektom branja glede na nosilec besedila - tisk na papirju ali črke na zaslonu. Tiska na papirju se je mogoče neposredno dotakniti in ga otipati, je fizično vezan na papir; besedilo na zaslonu je neoprijemljivo (neotipljivo in virtualno) in je ločeno od sredstva prikazovanja (Mangen \& Kuiken, 2014). Tiskana besedila se razlikujejo po volumnu, otipu papirja, zvoku obračanja listov, vonju, obarvanosti papirja, vezavi, obrabljenosti ipd. Digitalna besedila so bolj enaka, bolj ,ploska ' in ne glede na besedilo je naprava vedno ista. 
Knjiga zagotavlja bralcu večjo stalnost in trdnost. Psihološke raziskave kažejo, da pomanjkanje stalnosti in prostorsko-časovnih označevalcev, kot nam jih nudijo knjige, npr. ,pri vrhu leve strani na začetku knjigec, lahko v digitalnem okolju ovira bralno razumevanje (Kerr \& Symons, 2006).

Branje je utelešena in multisenzorna dejavnost, ki jo lahko raziskujemo preko fizioloških meritev (za čustva in zatopljenost v branje - pupilometrija, srčni utrip, prevodnost kože) ter z različnimi nalogami pozornosti in spomina, razumevanja besedil (globinsko-površinsko, semantično, sklepanje) in metakognicije ter s fenomenološkim subjektivnim izkustvenim poročanjem (COST-IS1404, 2014).

\section{Poglobljeno branje}

Raziskovalci so kot ključni del bralne pismenosti opredelili poglobljeno branje, ki vključuje več zahtevnih kognitivnih procesov, povezanih z razumevanjem, kot so sklepanje, kritična analiza, refleksija in vpogled (Wolf in Barzillai, 2009). Navezuje se na branje obsežnejšega kompleksnega besedila, ki zahteva tudi daljšo mentalno osredotočenost (romani, eseji in tudi neliterarna besedila).

Poglobljeno branje $z$ digitalizacijo upada. Povsod se srečujemo s skrajšanimi besedili literarnih, strokovnih in drugih del, s povzetki, z že vnaprej pripravljenimi odgovori, ki ne zahtevajo daljše pozornosti in vztrajnosti (COST-IS1404, 2014).

Čeprav ima lahko digitalno besedilo določene prednosti zaradi hitre dostopnosti do dodatnih informacij, slovarjev, diskusij ipd., je zaradi velikega števila možnosti in takojšnosti informacij ovira za poglobljeno branje in diskusijo.

Zato so potrebne dobro razvite eksekutivne (izvršilne) funkcije, samoregulativne sposobnosti, spretnosti načrtovanja in organiziranja dejavnosti, selekcioniranja in osmišljevanja informacij, nadzorovanja bralnega razumevanja, metakognitivnega zavedanja ipd.

Sposobnosti eksekutivnih (izvršilnih) funkcij, ki jih zahteva uspešno digitalno branje, kot so delovni spomin, pozornost, odločanje, evalvacija itd., se razvijajo kasneje $v$ življenju in so povezane $\mathrm{z}$ dozorevanjem prefrontalnega dela možganov, za katerega vemo, da se razvije pozneje in doseže polni razvoj šele okoli 20 . leta.

Hitra dostopnost do ogromne množice informacij učence zavede $\mathrm{v}$ prepričanje, da že posedujejo znanje, in si zato ne prizadevajo za razume- 
vanje in za poglabljanje znanja. Enostavnost pridobivanja instantnih informacij na svetovnem spletu daje študentom varljiv občutek, da so osvojili spretnosti pridobivanja znanja in da so te hitro pridobljene izgotovljene informacije že tudi njihovo znanje.

\section{Razlike med branjem besedil na papirju in na zaslonu}

$\mathrm{V}$ številnih raziskavah iščejo razloge in razlage za te razlike na širokem razponu od fizikalnih lastnosti nosilcev besedil, preko pozornosti, perceptivnih in kognitivnih procesov bralca do fenomenoloških/izkustvenih vidikov procesa branja. Besedilo na papirju je za bralca dosegljivo naenkrat in v celoti, medtem ko je besedilo na zaslonu omejeno na eno samo stran. Pri klasičnih virih bralec občuti prostorske in fizične dimenzije knjige, ki omogoča hitro rokovanje in konstruiranje mentalne predstave besedila (listanje, pregledovanje, preskakovanje, raziskovanje strukture itd.) ter sprejemanje različnih čutnih informacij o papirju, na katerem je natisnjeno besedilo (Mangen et al., 2013). Omejitev na eno samo stran na zaslonu pa otežuje hiter pregled organizacije, strukture in poteka besedila.

\section{Bralno razumevanje in metakognicija branja}

Anne Mangen je s sodelavci leta 2013 izvedla raziskavo na 72 učencih desetega razreda dveh osnovnih šol na Norveškem (Mangen et al., 2013). Želeli so ugotoviti, kako nosilec besedila (papir, zaslon) vpliva na bralno razumevanje. Rezultati so pokazali, da so učenci, ki so brali besedila na papirju, dosegli pomembno boljše rezultate na preizkusu bralnega razumevanja kot tisti, ki so brali besedila na zaslonu. Pri branju na zaslonu so prisotni novi dejavniki, ki vplivajo na dosežke bralca: premikanje besedila na zaslonu predstavlja dodatno kognitivno obremenitev, odsotnost prostorskih in časovnih označevalcev pri digitalnem besedilu negativno vpliva na pomnjenje in razumevanje besedila

Garner (1988) je dokazala, da sposobnost nadzorovanja lastnega kognitivnega delovanja pri branju (samoregulacija) korelira z dobrim razumevanjem prebranega. Ackerman in Goldsmith (2011) sta raziskovala, ali je mogoče razlike $\mathrm{v}$ rezultatih branja na papirju in zaslonu pripisati metakognitivnim procesom pri branju. V svoji raziskavi sta ugotovila, da osnovna razlika $\mathrm{v}$ dosežkih branja na papirju in zaslonu ni kognitivna ampak metakognitivna. Udeleženci so pri branju na zaslonu preveč samozavestno ozir. manj natančno napovedali svoje dosežke in tudi manj natančno nadzorovali čas za opravljanje naloge kot pri branju na papirju. Avtorja sta zaklju- 
čila, da imajo ljudje občutek, da je tiskani medij bolj primeren za učenje, pri katerem se je treba potruditi, medtem ko je elektronski medij (računalnik) bolj ustrezen za „hitro in plitvo branje kratkih besedil, kot so novice, e-pošta in novice na forumih".

V praksi je treba razmisliti, katera daljša zahtevnejša besedila je smiselno ohraniti $v$ tiskani obliki in katera manj zahtevna v e-obliki. Pomembno je tudi bralce spodbujati k razvoju strategij za prepoznavanje in razumevanje prebranega kot tudi za razvijanje sposobnosti načrtovanja in reguliranje procesa branja.

\section{Socialni in čustveni razvoj}

Vedno več raziskav potrjuje velik pomen branja leposlovnih del za emocionalni in socialni razvoj. $\mathrm{V}$ teh raziskavah so uporabljali različne psihometrične metode od opazovalnih tehnik in merjenja emocionalne dejavnosti bralca med in po branju literature do numerično podprtega fenomenološkega raziskovanja prvoosebne bralne izkušnje (Kuiken in Miall, 2001).

Branje literarnih del vpliva na razvoj in podporo socialnih in emocionalnih spretnosti, kot sta empatija in simpatija (Mar in Oatley, 20o8; Mason in Just, 2009).

Nekatere raziskave nakazujejo, da lahko uporaba tablic negativno vpli$v a$ na emocionalne vidike branja literarnih del, ki se razvijajo šele ob zatopljenosti v branje (Mangen in Kuiken, 2014).

Branje literarnih del vpliva tudi na verbalne spretnosti in intelektualne sposobnosti ter na razumevanje, kaj lahko drugi mislijo in občutijo - teorija uma (Kidd in Castano, 2013)2.

\section{Večopravilnost (multitasking) $\mathbf{v}$ digitalnem svetu}

Večopravilnost pomeni hkratno (simultano) izvajanje dveh ali več nalog lahko vključuje preskakovanje naprej ali nazaj od ene naloge do druge ali izvajanja večjega števila nalog $\mathrm{v}$ zelo hitrem zaporedju. Večopravilnost ni nekaj novega, vendar izpostavljenost nenehnemu toku informacij, ki nas preplavlja $\mathrm{v}$ digitalni dobi, predstavlja poseben pojav, ki ga imenujemo (digitalna) medijska večopravilnost. To je hkratna uporaba večjega števila različnih medijev, kot so medomrežje, video igre, televizor, telefon, pisanje sporočil in e-sporočil, Facebook, Instagram ipd. Poleg tega število različnih medijev stalno narašča in jih poleg odraslih vedno pogosteje uporablja-

2 Več v Tancig, 2008, 2016. 
jo tudi otroci in mladostniki. Ni redko, da pošiljajo sporočila, igrajo video igre, uporabljajo družabna omrežja, brskajo po medomrežju, medtem ko delajo domače naloge ali poslušajo predavanja.

Neredko se srečujemo $\mathrm{z}$ infomanijo, kompulzivno željo nenehnega preverjanja nakopičenih informacij in novic preko mobilnega telefona ali računalnika. Obsesivna želja biti na tekočem s sporočili in strah, da bomo kaj spregledali, zamudili, izpustili (FOMO - Fear Of Missing Out) ter hkratno pregledovanje različnih virov informacij, sta lahko močna ovira pri soočanju z življenjskimi nalogami in opravili v realnem svetu.

Možgani so postali preobremenjeni, k čemur veliko pripomorejo tudi pametni mobilni telefoni z najrazličnejšimi možnostmi uporabe (računalnik, slovar, koledar, Twitter, Facebook, fotografski aparat in album, čitalnik in knjižnica itd.). Pametni telefon je veliko močnejši in zmogljivejši kot najboljši računalniki pred 30 leti. Je stalni spremljevalec, ki ga nenehno uporabljamo v najrazličnejših položajih, priložnostih in dejavnostih.

Ko opravljamo vse te dejavnosti, hitro skačemo od ene naloge do druge in smo prepričani o svoji učinkovitosti, da smo opravili veliko število nalog, čeprav smo v resnici zelo neučinkoviti, kar potrjujejo številne raziskave.

\section{Večopravilnost, spremembe $v$ možganih, kognitivnih procesih in čustveno-socialni samonadzor}

S preklapljanjem med nalogami izgubljamo čas, čeprav mislimo ravno nasprotno, imamo vedno večje težave ostati na isti nalogi in se ji posvetiti $\mathrm{z}$ vso osredotočenostjo, kar močno vpliva na celotno delovno učinkovitost. Medtem ko izvajamo vse te različne naloge - telefoniranje, pisanje sporočil, pregledovanje pošte, brskanje po spletu - se zmanjšajo naše kognitivne in intelektualne sposobnosti.

Uporaba mobilnega telefona med vožnjo avtomobila predstavlja še posebno nevarnost in tveganje, ker se zmanjšata vidno in slušno zaznavanje ter pozornost, podaljša se čas odzivanja in poslabša prilaganje razmeram na cesti. Zato Agencija za varnost prometa (AVP) opozarja, da uporaba mobilnega telefona med vožnjo ni dovoljena in se zato kaznuje.

Večopravilnost poveča izločanje stresnega hormona kortizola kot tudi adrenalina, ki lahko pretirano stimulira naše možgane. Na dolgi rok lahko taka stresna stanja ogrožajo tudi zdravje. 
Psiholog in nevroznanstvenik Russell Poldrack posebej opozarja, da večopravilnost negativno vpliva na to, kako se učimo. Različne oblike učenja in spomina so odvisne od funkcionalnosti in strukture anatomsko ločenih živčnih omrežij. Skupaj s sodelavci je s slikanjem možganov (fMRI) ugotovil, da uporabljamo različna področja možganov za učenje in uskladiščenje informacij glede na to, ali smo osredotočeni samo na eno samo nalogo ali hkrati na večje število nalog, kot je to primer pri večopravilnosti (Foerde et al., 2006). V primeru učenja ene same naloge, na katero se osredotočimo z vso pozornostjo, je vključen hipokampus, ki je pomemben za ustvarjanje bogatih in prožnih spominov. Informacije so dobro organizirane in kategorizirane ter jih zlahka prikličemo in uporabimo v novem položaju. Pri takem učenju je naša sposobnost generalizacije (posploševanja) pridobljenega znanja zelo dobra.

V primeru večopravilnosti se kaže večja aktivnost v striatumu, področju, ki je specializirano za učenje nove spretnosti ali postopka. Znanje, ki ga pridobimo v tem primeru, ni tako prožno in je bolj specializirano. Težje ga prikličemo in manj smo ga sposobni posplošiti ter uporabiti v novem položaju. Morda to deloma vpliva tudi na manjšo ustvarjalnost.

S sistematičnimi študijami so tudi odkrili, da se zmanjša naše razumevanje gradiva, če smo v bližini nekoga, ki uporablja računalnik, saj nam naša pozornost nehote uhaja nanj, ker skušamo ugotoviti, kaj ta oseba gleda in dela (Sana et al., 2013).

Veliko raziskav $\mathrm{z}$ večopravilnostjo in različnimi spremenljivkami so opravili na Univerzi Stanford, da bi čim bolje pojasnili večopravilnost. V eni od študij je raziskovalec Nass s sodelavci (Ophir et al., 20og) ugotovil, da so osebe, ki pogosto uporabljajo večopravilnost, slabše v ločevanju pomembne informacije od nepomembnih. Poleg tega imajo več težav v preklapljanju z ene naloge na drugo in so miselno manj organizirani. Še bolj nepričakovana je bila ugotovitev, da so enaki rezultati prisotni tudi v primeru, ko niso bili vključeni v dejavnost večopravilnosti. Pokazalo se je, da so osebe, ki pogosto izvajajo večopravilnost, tudi pri osredotočanju na eno samo nalogo manj učinkovite in manj uspešne. Tudi sicer so slabše v različnih kognitivnih procesih, predvsem pri zahtevnejših.

Da bi dobili podrobnejši vpogled, kaj se dogaja v možganih pri osebah, ki so zelo pogosto aktivne $\mathrm{v}$ večopravilnosti, in $\mathrm{v}$ njihove psihosocialne značilnosti, so izvedli raziskavo povezav med večopravilnostjo in možgansko strukturo. $\mathrm{V}$ raziskavi so med drugim uporabili tudi osebnostne teste (Loh in Kanai, 2014). S slikanjem možganov so pri osebah, ki pogos- 
to uporabljajo večopravilnost, odkrili, da ima sprednji cingulatni korteks manjši volumen sive snovi, kar se verjetno povezuje $\mathrm{z}$ ugotovljeno zmanjšano kognitivno kontrolo in slabšo socialno-emocionalno regulacijo teh oseb (so bolj impulzivne in slabše kontrolirajo svoje vedenje) (ibid.). Čeprav ta kot tudi podobne korelacijske študije ne omogočajo sklepa, kaj je vzrok in kaj posledica, so rezultati raziskave osvetlili nove povezave med večopravilnostjo in strukturnimi spremembami v možganih. Predvsem pa je pomembno zavedanje, da pri uporabi digitalne medijske večopravilnosti ne gre samo za funkcionalne spremembe $v$ možganih temveč tudi za strukturne, ki se odražajo v spremembah kognitivnih procesov in vedenja.

Glede na to, da večopravilnost narašča tudi med otroki in mladostniki, katerih možgani se še razvijajo, je dobro poznavanje in razumevanje in kognitivnih posebnosti digitalne medijske večopravilnosti pomembna naloga. Raziskovalci so skušali empirično preveriti, kakšne so povezave med večopravilnostjo in učnim uspehom.

\section{Večopravilnost in učna uspešnost}

Ena novejših raziskav je preverjala odnos med medijsko večopravilnostjo (MV), opravljanjem domačih nalog, izvršilnimi (eksekutivnimi) funkcijami in učno uspešnostjo pri mladostnikih (Martín-Perpiñá et al., 2019). Rezultati raziskave so pokazali, da je pogosta MV med opravljanjem domačih nalog $\mathrm{v}$ negativnem odnosu $\mathrm{z}$ izvršilnimi funkcijami in učno uspešnostjo. Mladostniki so poročali o več težavah, povezanih z izvršilnimi funkcijami v vsakodnevnem življenju, s slabšim kognitivnim delovanjem glede komponent delovnega spomina, hitrosti procesov ter nižje uspešnosti v jeziku in matematiki. Raziskovalci so predlagali razvijanje strategij, ki bi mladostnikom omogočale osredotočanje pozornosti na naloge, in izogibanje motečim dejavnikom.

V pregledni raziskavi (sinteza večjega števila študij) se je pokazal negativen odnos med MV in učno uspešnostjo (May in Elder, 2018). Ugotovljeno je bilo, da MV interferira s pozornostjo in delovnim spominom, negativno vpliva na učno uspešnost, priklic, bralno razumevanje, delanje zapiskov, samoregulacijo in učinkovitost. Ta učinek se je pokazal tako pri pouku v razredu kot pri učenju. Pokazalo se je tudi, da imajo učenci velike težave pri točni oceni vpliva MV na svojo učno uspešnost. Avtorji raziskave navajajo možnost za izboljšanje učne uspešnosti s spodbujanjem samoregulacije.

V obsežni pregledni študiji so raziskovali povezave MV s spremenljivkami na kognitivnem področju (Uncapher et al., 2016, 2017). Pri učencih, ki 
zelo pogosto izvajajo MV, so se pokazale razlike v kogniciji (npr. slabše spominske funkcije - delovni in dolgoročni spomin), v psihosocialnem vedenju (npr. povečana impulzivnost) in na nevrološkem področju (zmanjšan volumen sprednjega cingulatnega korteksa - verjetno se to povezuje s povečano impulzivnostjo, slabšo čustveno kontrolo). Polega tega so raziskave odkrile, da lahko MV negativno vpliva na učno uspešnost ne glede na to, ali se izvaja v razredu ali doma.

Pomembna je pregledna raziskava problematike $\mathrm{MV}$ in učne uspešnosti pri mladostnikih, v kateri so avtorji integrirali ugotovitve večjega števila študij, v katerih so bili raziskani tudi odnosi MV z nekaterimi spremenljivkami na področju kognitivne kontrole in socialno-čustvenega področja (Schuur et al., 2015). Rezultati te pregledne raziskave so pokazali negativen odnos med MV in nekaterimi vidiki kognitivne kontrole (npr. fokusirana pozornost na relevantne informacije), med MV in socialno-čustvenim delovanjem (npr. depresija in socialna anksioznost, socialna uspešnost) ter negativen odnos med MV in učno uspešnostjo.

\section{Zaključek}

Digitalna tehnologija prinaša prednosti in hkrati tveganja. Obe dejavnosti klasično opismenjevanje (pisanje in uporaba tiskanih gradiv na papirju) ter uporabo digitalnih pripomočkov - je treba smiselno uskladiti. Spremembe, ki jih vnašamo v šolski prostor, morajo biti premišljene in znanstveno podprte. Predvsem pa je pomembno ohraniti poglobljeno branje in branje daljših in zahtevnejših besedil, ki pomembno prispevata k razvoju reflektivnega in kritičnega mišljenja ter k čustveno-socialnemu razvoju.

Dobro je vedeti, da branje ni del naše genetske opremljenosti. Branje je staro 5400 let, kar je daleč prekratko obdobje, da bi razvili posebno omrežje v možganih za branje. Bralno omrežje razvijamo v času svojega življenja $\mathrm{z}$ učenjem in $\mathrm{z}$ vplivi okolja, kar je mogoče zaradi plastičnosti možganov. Prav tako velja tudi pravilo »uporabi ali izgubi« (use it or lose it).

Zato bi bilo smiselno upoštevati glavne ugotovitve raziskav in priporočila že omenjene Deklaracije iz Stavangerja o prihodnosti branja (COST-IS1404, 2019) za edukacijsko politiko in vzgojno-izobraževalno prakso. 


\section{Literatura}

Ackerman, Rakefet in Morris Goldsmith. 2011. »Metacognitive Regulation of Text Learning: On Screen versus on Paper.« Journal of Experimental Psychology: Applied 17 (1): 18-32. doi: 10.1037/a0022086.

Berninger, Virginia W., Judith E. Rutberg, Robert D. Abbott, Noelia Garcia, Marci Anderson-Youngstrom, Allison Brooks in Cynthia Fulton. 2006. »Tier 1 and Tier 2 Early Intervention for Handwriting and Composing." Journal of School Psychology 44 (1): 3-30. doi: 10.1016/j.jsp.2005.12.003.

COST-IS1404. 2014. Memorandum of Understanding for the implementation of a European Concerted Research Action designated as COST Action IS1404: Evolution of reading in the age of digitisation (E-READ). http:// www.cost.eu/COST_Actions/isch/IS1404. (22. 2. 2016).

COST-IS1404. 2019. Deklaracija iz Stavangerja o prihodnosti branja. http://ereadcost.eu/stavanger-declaration/. (25. 4. 2019.)

Dehaene, Stanislas. 2014. "Reading in the Brain Revised and Extended: Response to Comments." Mind \& Language 29 (3): 320-35. doi: 10.1111/ mila.12053.

Demšar, Ema. »Experiential Differences between Typing and Handwriting «. Proceedings of the MEi:CogSci Conference 2015: 95, Ljubljana, 2015.

Foerde, Karin, Barbara J. Knowlton in Russell A. Poldrack. 2006. »Modulation of Competing Memory Systems by Distraction. « Proceedings of the National Academy of Sciences 103 (31): 11778-11783. doi: 10.1073/pnas.0602659103.

Gallese, Vitorio in George Lakoff. The brain's concept: The role of the sensory-motor system in conceptual knowledge. Cognitive Neuropsychology 22. (2005): 455-479.

Garner, Ruth. 1988. Metacognition and Reading Comprehension. Norwood, NJ: Ablex.

Gibson, James J. 1979. The Ecological Approach to Visual Perception. Boston: Houghton Mifflin.

Glenberg, Arthur M. 2008. Embodiment for education. V Paco Calvo \& Toni Gomila (ured.), Handbook of cognitive science: An embodied approach; 355-372. Amsterdam, The Netherlands: Elsevier.

James, Karin H. 2012. »How Printing Practice Affects Letter Perception: An Educational Cognitive Neuroscience Perspective."Presented at Handwriting in the 21st Century?: An Educational Summit. Washington, D.C., January 23, 2012. 
James, Karin H. in Laura Engelhardt. 2012. »The Effects of Handwriting Experience on Functional Brain Development in Pre-Literate Children." Trends in Neuroscience and Education 1 (1): 32-42. doi: 10.1016/j.tine.2012.08.001.

Kerr, Matthew A. in Sonya E. Symons. 2006. „Computerized Presentation of Text: Effects on Children's Reading of Informational Material.« Reading and Writing 19 (1) 1-19. doi: 10.1007/s11145-003-8128-y.

Kersey, Alyssa J. in Karin H. James. 2013. »Brain Activation Patterns Resulting from Learning Letter Forms through Active Self-Production and Passive Observation in Young Children.« Frontiers in Psychology 4 (567). doi: 10.3389/fpsyg.2013.00567.

Kidd, DavidC. in Emanuele Castano. 2013. »Reading Literary Fiction Improves Theory of Mind.« Science 342 (6156): 377-80. doi: 10.1126/science.1239918.

Kiefer, Markus in Natalie M. Trumpp. 2012. Embodiment theory and education: The foundations of cognition in perception and action. Trends in $\mathrm{Ne}$ uroscience and Education 1 (1): 15-20. doi: 10.1016/j.tine.2012.07.002.

Kiefer, Markus in Friedemann Pulvermüller. 2012. Conceptual representations in mind and brain: Theoretical developments, current evidence and future directions. Cortex 48 (7): 805-825. doi: 10.1016/j.cortex.2011.04.006.

Kiefer, Markus in Lawrence W. Barsalou. 2013. „Grounding the Human Conceptual System in Perception, Action in Internal States."Action Science (January) 381-407. doi: 10.7551/mitpress/9780262018555.003.0015.

Kuiken, Don in David S. Miall. 2001. Numerically aided phenomenology: Procedures for investigating categories of experience. FQS - Forum: Qualitative Social Research 2 (1). doi: 10.17169/fqs-2.1.976

Loh, Kep Kee in Ryota Kanai. 2014. »Higher Media Multi-Tasking Activity Is Associated with Smaller Gray-Matter Density in the Anterior Cingulate Cortex.«PLoS ONE 9 (9). doi: 10.1371/journal.pone.0106698.

Longcamp, Marieke, Céline Boucard, Jean-Claude Gilhodes in Jean-Luc Velay. 2006. "Remembering the Orientation of Newly Learned Characters Depends on the Associated Writing Knowledge: A Comparison between Handwriting and Typing." Human Movement Science 25 (4-5): 646-56. doi: 10.1016/j.humov.2006.07.007.

Longcamp, Marieke, Yevhen Hlushchuk in Riitta Hari. 2010. »What Differs in Visual Recognition of Handwritten vs. Printed Letters? An FMRI Study.« Human Brain Mapping 32 (8) 1250-59. Doi: 10.1002/hbm.21105.

Mangen, Anne, Bente R. Walgermo in Kolbjørn Brønnick. 2013. »Reading Linear Texts on Paper versus Computer Screen: Effects on Reading Com- 
prehension.« International Journal of Educational Research 58: 61-68. doi:10.1016/j.ijer.2012.12.002.

Mangen, Anne in Don Kuiken. 2014. "Lost in an iPad: Narrative engagement on paper and tablet.« Scientific Study of Literature 4 (2): 150-77. doi: 10.1075/ssol.4.2.02man.

Mangen, Anne in Adriaan Van Der Weel. 2016. »The Evolution of Reading in the Age of Digitisation: an Integrative Framework for Reading Research.« Literacy 50 (3): 116-24. doi: 10.1111/lit.12086.

Mar, Raymond A. in Keith Oatley. 2008. »The Function of Fiction Is the Abstraction and Simulation of Social Experience." Perspectives on Psychological Science 3 (3): 173-92. doi: 10.1111/j.1745-6924.2008.00073.x.

Martín-Perpiñá, Maria de las Mercedes, Ferran Viñas Poch in Sara Malo Cerrato. 2019. "Media multitasking impact in homework, executive function and academic performance in Spanish adolescents". Psicothema 31 (1): 8187, doi: 10.7334/psicothema2018.178.

Mason, Robert A. in Marcel Adam Just. 2009. »The Role of the Theory-of-Mind Cortical Network in the Comprehension of Narratives."Language and Linguistics Compass 3 (1): 157-74. doi: 10.1111/j.1749-818x.2008.00122.x.

May, Kaitlyn E. in Anastasia D. Elder. 2018. »Efficient, Helpful, or Distracting? A Literature Review of Media Multitasking in Relation to Academic Performance." International Journal of Educational Technology in Higher Education 15 (1). doi: 10.1186/s41239-018-0096-Z.

Mueller, Pam A. in Daniel M. Oppenheimer. 2014. »The Pen Is Mightier Than the Keyboard." Psychological Science 25 (6): 1159-68. doi: 10.1177/0956797614524581.

Nakamura, K., W.-J. Kuo, F. Pegado, L. Cohen, O. J. L. Tzeng in S. Dehaene. 2012. »Universal Brain Systems for Recognizing Word Shapes and Handwriting Gestures during Reading."Proceedings of the National Academy of Sciences 109 (50): 20762-67. doi: 10.1073/pnas.1217749109.

Ophir, Eyal, Clifford Nass in Anthony D. Wagner. 2009. "Cognitive Control in Media Multitaskers."Proceedings of the National Academy of Sciences 106 (37): 15583-87. doi: 10.1073/pnas.0903620106.

Sana, Faria, Tina Weston in Nicholas J. Cepeda. 2013. »Laptop Multitasking Hinders Classroom Learning for Both Users and Nearby Peers.« Computers \& Education 62: 24-31. doi: 10.1016/j.compedu.2012.10.003.

Schuur, Winneke A. Van Der, Susanne E. Baumgartner, Sindy R. Sumter in Patti M. Valkenburg. 2015. »The Consequences of Media Multitasking for 
Youth: A Review.« Computers in Human Behavior 53: 204-15. doi: 10.1016/j. chb.2015.06.035.

Tancig, Simona. 2008. »Razvoj empatije, teorije uma in metareprezentacije: interdisciplinarni pogledi.« V Marko Bohanec, Darja Mladenić, Marko Grobelnik, Milan Heričko, Urban Kordeš in Olga Markič (ured.), Zbornik 11. mednarodne multikonference Informacijska družba - IS 20o8, 13.17. oktober 20o8: zvezek A (Kognitivna znanost): 353-357, Ljubljana: Institut „Jožef Stefan“.

Tancig, Simona. 2014. "Kako branje spreminja možgane in kaj izgubimo, če pisanje nadomestimo s tipkanjem?« V Mojca Orel (ur.), Zbornik prispevkov na mednarodni konferenci EDUvision 2014, 27.-28. november 2014: 11-19, Ljubljana,.

Tancig, Simona. 2014a. "Novejša spoznanja nevroedukacijske znanosti o specifičnih učnih težavah." Vabljeno predavanje; Otroci in mladostniki s specifičnimi učnimi težavami - podpora pri uresničevanju njihovih potencialov. Zbornik prispevkov Četrte mednarodne konference o specifičnih učnih težavah: 72-82. Ljubljana: Društvo Bravo.

Tancig, Simona. 2014b. »Nevroedukacija in utelešena kognicija - pogledi na gibalno in plesno dejavnost «. Plenarno predavanje. V Vesna Geršak in Nina Meško (ured.) Zbornik 2. Mednarodne konference plesne pedagogike: 11. Velenje: Javni sklad RS za kulturne dejavnosti.

Tancig, Simona. 2016. »Od Prousta do Twitterja - nevroedukacijske raziskave bralne pismenosti v digitalni dobi.« V Tatjana Devjak, Igor Saksida, Dagarin Fojkar, (ured.). Bralna pismenost kot izziv in odgovornost: 9-26. 1. izd. Ljubljana: Pedagoška fakulteta.

Thompson, Evan T. 2007. Life in mind: Biology, phenomenology, and the sciences of the mind. Cambridge, MA: Harvard University Press.

Uncapher, Melina R., Monica K. Thieu in Anthony D. Wagner, A.D. (2016). "Media multitasking and memory: Differences in working memory and long-term memory”. Psych. on Bull. Rev. 23 (2): 483-49o. doi: 10.3758/ s13423-015-0907-3.

Uncapher, Melina R., Lin Lin, Larry D. Rosen, Heather L. Kirkorian,, Naomi S. Baron, Kira Bailey, Joanne Cantor, David L. Strayer, Thomas D. Parsons in Anthony D. Wagner. (2017). "Media Multitasking and Cognitive, Psychological, Neural in Learning Differences”. Pediatrics 140 (s2), doi: 10. 1542/ peds. 2016-1758D. 
Varela, Francisco J., Thompson, Evan T. in Eleanor Rosch. 1991. The embodied mind: Cognitive science and human experience. Cambridge, MA: MIT Press.

Wolf, Maryanne in Mirit Barzillai, M. 2009. The importance of deep reading. Educational Leadership 66 (6), 32-37. 